\title{
Synthetic musk fragrances and heavy metals in snow samples of Beijing urban area, China
}

\author{
Zhengjun Hu, Yali Shi, Hongyun Niu, Yaqi Cai* \\ State Key Laboratory of Environmental Chemistry and Ecotoxicology, Research Center of Eco-Environmental Sciences, Chinese Academy of Sciences, P.O. Box 2871, Beijing \\ 100085, China
}

\section{A R T I C L E I N F O}

\section{Article history:}

Received 30 August 2010

Received in revised form 6 August 2011

Accepted 6 September 2011

\section{Keywords:}

Synthetic musk fragrances

Metals

Snow samples

China

\begin{abstract}
A B S T R A C T
Seven typical synthetic musk fragrances (musk xylene (MX), musk ketone (MK), Galaxolide (HHCB), Tonalide (AHTN), Celestolide (ADBI), Traseolide (ATII) and Phantolide (AHMI)) and seventeen heavy metals ( $\mathrm{Al}, \mathrm{V}, \mathrm{Cr}, \mathrm{Mn}, \mathrm{Co}, \mathrm{Ni}, \mathrm{Cu}, \mathrm{Zn}, \mathrm{As}$, Se, Mo, $\mathrm{Ag}, \mathrm{Cd}, \mathrm{Sb}, \mathrm{Ba}$, Ti and $\mathrm{Pb}$ ) were measured in 42 snow samples from Beijing urban area of China. Galaxolide (HHCB) and Tonalide (AHTN) showed the highest concentrations (6.5-75.1 and 2.2-16.4 ng/l, respectively) and highest detection frequency (nearly 100\%) among the musks. MX, MK and ATII were only found in several samples. HHCB concentrations were not significantly relative with DOC, while AHTN concentrations were found positively correlated with DOC $(p<0.05)$. Moreover, $\mathrm{Mn}, \mathrm{Zn}, \mathrm{Sb}, \mathrm{Ba}, \mathrm{Cu}$ and As could be detected in most of snow samples, ranged in N.D. $-71.3 \mu \mathrm{g} / \mathrm{L}$. No significant correlation was observed in metal concentrations and DOC $(p>0.05)$. Significant correlations exist between the concentrations of HHCB and AHTN in snow samples $(p<0.001)$ of Beijing, China.
\end{abstract}

(c) 2011 Elsevier B.V. All rights reserved.

\section{Introduction}

Snow is important for the troposphere and the ecosystem because of the influence on energy balances and hydrological fluxes. As an important long-range transport media, snow has also been proved to be an effective scavenger to the removal of pollutants from atmosphere both in temperate and polar regions (Lei and Wania, 2004). There are numerous reports about occurrence of natural and synthetic compounds in snow samples, such as polycyclic aromatic hydrocarbons (PAHs) (Masclet et al., 2000; Zhang et al., 2008); polychlorinated biphenyls (PCBs) (Lafrenère et al., 2006;Wania et al., 1998), organochlorine pesticides (OCPs)( Lafrenère et al., 2006; Huang et al., 2010), methyl tert-butyl ether (MTBE) (Kolb and Püttmann, 2006) , 4-nonylphenol(4-NP)(Fries and Püttmann, 2004) and so on.

Synthetic musk fragrances (SMs) have been widely used in a variety of personal care products and household cleaners as

\footnotetext{
* Corresponding author. Tel./fax: + 861062849182.

E-mail address: caiyaqi@rcees.ac.cn (Y. Cai).
}

well as in technical products and consume goods (Richardson, 2009). Nitro and polycyclic musks are used more frequently than other kinds of musks. Now, polycyclic musks nearly occupy the main musk market of the world (Käfferlein and Angerer, 2001). In recent years, more and more studies have reported the potential estrogenic and anti-estrogenic effects of the polycyclic musks (Yamauchi et al., 2008). At the same time, they have been found in many types of environmental matrices and biota samples, such as wastewater, sewage sludge, fish, breast milk, and indoor dust and so on(Reiner et al., 2007; Guo et al., 2010; Lignell et al., 2008; Wan et al., 2007; Peck and Hornbuckle, 2006). SMs are lipophilic, persistent and bioaccumulative in the aquatic environment and biota samples, which are similar with those of PAHs and PCBs and so on (Wania et al., 1998). Therefore, musks may be also detected in the snow samples. However, there is little information about the occurrence of synthetic musk fragrances in snow samples.

Many heavy metals would be emitted into atmosphere with the increase of population density and anthropogenic activities (Zheng et al., 2010). Toxic metals have been 
observed in atmosphere, such as $\mathrm{Pb}, \mathrm{Cd}, \mathrm{Zn}, \mathrm{Cr}$ and As and so on (Schneidemesser et al., 2010). As scavenger of atmosphere, snow plays an important role. However, there is little information about the distributions and concentrations of heavy metals in snow samples in Beijing of China.

In the present study, 42 snow samples from urban area of Beijing were collected. Seven typical SMs, seventeen heavy metals, pH values and dissolved organic compounds (DOC) of the snow samples were analyzed. The objective of the present study is mainly to investigate the occurrence of SMs and heavy metals in snow samples. This is the first report about synthetic musk fragrance concentrations in snow samples.

\section{Experimental}

\subsection{Materials and methods}

Seven musk standards (AHTN, HHCB, ADBI, AHMI, ATII, MK and MX), surrogate standard $d_{3}$-AHTN and internal standard $(\mathrm{HCB}){ }^{13} \mathrm{C}_{6}$ were obtained from Dr. Ehrestorfer (Augsburg, Germany). C-18 discs were from Supeclo ( $\varnothing$ $47 \mathrm{~mm}$, Bellefonte, USA).

\subsection{Sampling}

42 snow samples were collected directly from snow layers at the urban area of Beijing on November 11 2009. To avoid contamination, sampling sites are far away from any road traffic. Sampling sites were shown in Fig. 1. After melting, all samples were transferred into precleaned amber glass bottles and kept at $4{ }^{\circ} \mathrm{C}$ until analysis. Before extraction, the melted snow samples were filtered through nylon film $(0.45 \mu \mathrm{m})$. Sample extraction and analysis method were in Appendix A.

\subsection{Quality control and quality assurance}

In the present study, $d_{3}$-AHTN and $\mathrm{HCB}{ }^{13} \mathrm{C}_{6}$ were used as surrogate standard and internal standard, respectively. Recoveries of the $d_{3}$-AHTN were in the range of $89.7 \%-104.9 \%$. HCB ${ }^{13} \mathrm{C}_{6}$ was used to quantify musk concentrations. The reported concentrations of samples had been corrected using recovery of $d_{3}$-AHTN, which would be spiked into samples before pretreatment.

For calibration purposes, six different concentrations of musk standard solutions were analyzed by GC-MS. A standard calibration was performed. Correlation coefficient $R^{2}$ are $>0.99$. Matrix spike recovery studies were carried out. The limits of detection (LODs) of musks based on a signal-to-noise ratio of 5 were in the range of $1.2-$ $4.0 \mathrm{ng} / \mathrm{l}$. To avoid the possible contamination, all glassware was soaked in $\mathrm{K}_{2} \mathrm{Cr}_{2} \mathrm{O}_{7}-\mathrm{H}_{2} \mathrm{SO}_{4}$ lotion for at least $12 \mathrm{~h}$, and all equipment was rinsed with acetone in advance. A procedural blank was processed with each batch of 6 samples. Furthermore, a field blank was included during sampling. The all musk concentrations were below detection limits in all the blank samples.

\subsection{Statistical analysis}

Differences in musk concentrations and metals in snow samples from south and north were calculated using the Mann-Whitney $U$ test. A p-value below 0.05 was considered significant. All the statistical analyses were performed by the software of SPSS 13.0.

\section{Results and discussions}

\subsection{Musk concentrations in snow samples}

Two polycyclic musks, HHCB and AHTN, were observed in all the snowmelt samples. The concentrations of AHTN and HHCB were in the range of 2.2-205.9 ng/l (mean: $11.0 \mathrm{ng} / \mathrm{l}$ ), and 6.5-754.1 ng/l (mean: $33.3 \mathrm{ng} / \mathrm{l}$ ), respectively. MX and MK were detected in 4 and 5 snow samples, ranged in 4.416.1 and $6.7-43.2 \mathrm{ng} / \mathrm{l}$, respectively. ATII was only found in one snowmelt sample $(8.4 \mathrm{ng} / \mathrm{l})$. Other musks were all below the detection limits. It should be noted that musk concentrations from sampling spot A were much higher than those from other sampling spots (HHCB: $754.1 \mathrm{ng} / \mathrm{l}$; AHTN: $205.9 \mathrm{ng} / \mathrm{l}$ ). However, for other sampling spots they were in the range of 6.5-75.1 (mean: 15.7) $\mathrm{ng} / \mathrm{l}$ and 2.2-16.4

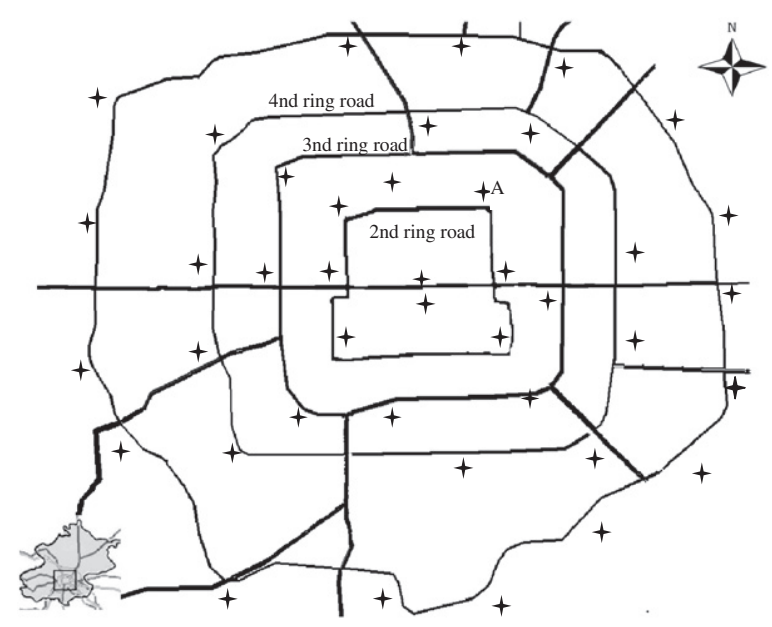

Fig. 1. Sampling sites of snow samples in Beijing urban area of China. 
(mean: 6.3) ng/L, respectively. Because there is no other study reporting the occurrence of synthetic musks, comparisons were only conducted between concentrations of musks and other organic compounds in snow samples, such as 4$\mathrm{NP}, \mathrm{PAH}$ and PCB and so on. The results showed that musk concentrations were slightly higher than OCP concentrations detected in Mt. Qomolangma (20-1650 pg/L)(Wang et al., 2007) and slightly lower than levels of 4-NP reported in Germany (ND-0.802 $\mu \mathrm{g} / \mathrm{L}$ )(Fries and Püttmann, 2004). Compared with PAH, levels of SMs were also lower than those of PAH reported both in Greenland (Masclet et al., 2000) and USA (Franz and Eisenreich, 1998), up to $100-10000 \mathrm{pg} / \mathrm{g}$ and $18 \mu \mathrm{g} / \mathrm{L}$, respectively. Additionally, SMs levels in the present study were comparable with levels of PCB in USA ( $7.9 \mathrm{ng} / \mathrm{L}$ ) (Franz and Eisenreich, 1998) and MTBE (16-127 ng/l) (Kolb and Püttmann, 2006) in Germany. To obtain direct knowledge about SMs pollution, comparison was also conducted between snows and effluents from wastewater treatment plants. The results showed that musk concentrations were also slightly lower than those in effluents from wastewater treatment plants of Beijing (Zhou et al., 2009; Hu et al., 2011). Moreover, Mann-Whitney $U$ test was conducted. The results showed no significant geography-related statistical difference was observed in the concentration of HHCB and AHTN ( $p>0.05)$.

Significant positive relationship was found between $\mathrm{HHCB}$ and AHTN concentrations $(p<0.001)$. The feature is similar with those found in human blood (Hu et al., 2010), influents, effluents and sewage sludge of wastewater treatment plants of Beijing reported by our group. As to the ratios of HHCB/ AHTN, they were detected in the range of 0.68-14.99 (median: 2.68) in the present study. The value was also similar with those found in human blood samples (about 2.3) collected from 11 cities of China (Hu et al., 2010). It was reported that ratios of $\mathrm{HHCB} / \mathrm{AHTN}$ would show decreasing trends during transport, because HHCB is quickly removed by atmospheric degradation relative to AHTN. Their ratios could be low to $0.1-0.4$ (Xie et al., 2007). Apparently, our results were much higher than the values. The phenomena could be explained by the fact that much of musks would be emitted into atmosphere every day and input of $\mathrm{HHCB}$ and AHTN could decrease influence on ratios from degradation of the two compounds.

\subsection{Heavy metals in snow samples}

In the present study, seventeen metals were measured, including $\mathrm{Al}, \mathrm{V}, \mathrm{Cr}, \mathrm{Mn}, \mathrm{Co}, \mathrm{Ni}, \mathrm{Cu}, \mathrm{Zn}$, As, Se, Mo, Ag, Cd, Sb, $\mathrm{Ba}$, Ti and $\mathrm{Pb}$, shown in Table 1 (Appendix $\mathrm{B}$ ). The results showed that detection frequencies of metals ( $\mathrm{Mn}, \mathrm{Zn}, \mathrm{Sb}$, $\mathrm{Ba}, \mathrm{Cu}$ and $\mathrm{As}$ ) were higher than those of other metals in the snow samples. Especially Mn, Zn, Sb and Ba, they could be detected in all the samples. $\mathrm{Cu}$ and As could be found in nearly $67 \%$ and $83 \%$ of snow samples, respectively. Cd was found in 4 snow samples, and $\mathrm{Ni}$ and $\mathrm{Cr}$ could be only detected in 7 and 5 samples in the present study. Be, $\mathrm{Co}, \mathrm{Ag}$ and $\mathrm{Ti}$ was not detected in all the 42 snow samples. Other metals including $\mathrm{Al}, \mathrm{V}, \mathrm{Se}, \mathrm{Mo}, \mathrm{Pb}$ and Se could be observed in about 8-18 snow samples. In the present study, the concentrations of $\mathrm{Mn}, \mathrm{Zn}, \mathrm{Sb}, \mathrm{Ba}, \mathrm{Cu}$ and As were in the range of $1.16-54.62 \mu \mathrm{g} / \mathrm{L}, \quad 3.91-71.33 \mu \mathrm{g} / \mathrm{L}, \quad 0.55-2.86 \mu \mathrm{g} / \mathrm{L}, \quad 2.80$ $65.93 \mu \mathrm{g} / \mathrm{L}$, N.D. $-9.63 \mu \mathrm{g} / \mathrm{L}$ and N.D.-3.36 $\mu \mathrm{g} / \mathrm{L}$, respectively.
It was concluded that the concentrations of $\mathrm{Zn}$ were higher than those of $\mathrm{Cu}$. The phenomena were similar with those reported by Wang et al. (2001). They reported that the $\mathrm{Zn}$ concentrations were higher than those of $\mathrm{Cu}$ in atmospheric particle matter (APM) not only in winter time with heavy coal combustion but also in summer time without heavy coal combustion. In the present study, the concentrations of $\mathrm{Al}$ were in the range of 0.1 $3.5 \mu \mathrm{g} / \mathrm{L}$, which were lower than $\mathrm{Al}^{3+}$ concentrations detected in snow samples $(106-783 \mu \mathrm{g} / \mathrm{L})$ as well as in rainwater (3.51-196.56 $\mu \mathrm{g} / \mathrm{L})$ from Beijing, reported by $\mathrm{Xu}$ and Han (2009) in 2006. Mann-Whitney $U$ test showed that the concentrations of $\mathrm{Mn}, \mathrm{As}, \mathrm{Sb}$ and Ba were higher in the southern samples than those in northern snow samples $(p<0.05)$. Nevertheless, there was no relationship between geography and concentrations of $\mathrm{Cu}$ and $\mathrm{Zn}(p>0.05)$.

In the present day, DOC values were detected in the range of 0.15-8.1 (mean: $1.19 \mathrm{mg} \mathrm{C/L}$ ). The values were much lower than those detected in Japan in 1993 (mean: $14.1 \mathrm{mg} \mathrm{C} / \mathrm{L}$ ) (Sempére and Kawamura, 1994) and in USA in 1992(mean: 4.5-18.4 mg C/L)(Franz and Eisenreich, 1998). $\mathrm{pH}$ in snow sample of Beijing urban area was in the range of 5.26-6.50. It was reported that $\mathrm{pH}$ values were 4.63 and 5.53 in snow samples of Beijing detected in 2006(Xu and Han, 2009). Apparently, our results were higher than those years ago.

\subsection{Relationships between DOC and concentrations of musks,} heavy metals

In the present study, the relationships between DOC and musk concentrations (HHCB and AHTN), metals were investigated. The results showed that positive correlations existed between AHTN and DOC concentrations $(p<0.01)$. However, there was no correlation between HHCB and DOC concentrations $(p>0.05)$. There was also no significant statistical relationship observed between DOC and metals. Different from our results, Chen et al. (2010) have reported that positive correlations existed between TOC and metals, including $\mathrm{Cd}, \mathrm{Cu}, \mathrm{Zn}$ and $\mathrm{Pb}$, in soil samples from Beijing area.

\section{Conclusions}

We measured the levels of seventeen typical SMs in snow samples collected in urban area of Beijing, China. High detection frequencies of SMs in snow samples may provide an indication that wet deposition would be an important removal pathway of synthetic musks from the atmosphere. Among the musks, HHCB and AHTN were the most abundant compounds. The levels of HHCB and AHTN in the present study were comparable with the snow concentrations of PCB in USA and MTBE in Germany, but slightly lower than 4-NP concentrations in Germany and PAH concentrations from Greenland and USA. Musk concentrations in the present study were also lower than those of effluents in wastewater treatment plants in Beijing. $\mathrm{Mn}, \mathrm{Cu}, \mathrm{Zn}, \mathrm{As}, \mathrm{Sb}$ and Ba could be detected in most of the snow samples. The Al concentrations were lower than those detected in snow and rainwater of Beijing in 2006. Additionally, pH values were higher, while DOC values were lower, compared with those detected in 2006. 
Supplementary materials related to this article can be found online at doi:10.1016/j.atmosres.2011.09.002.

\section{Acknowledgments}

The present work was jointly supported by the National Natural Science Foundation of China (Nos. 20837003, 20890111 and 20921063) and the Major State Basic Research Development Program of China (No. 209CB421605).

\section{References}

Chen, X., Xia, X., Zhao, P., Zhao, Y., 2010. Heavy metal concentrations in roadside soils and correlation with urban traffic in Beijing, China. J. Hazard. Mater. 181 (1-3), 640-646.

Franz, T.P., Eisenreich, S.J., 1998. Snow scavenging of polychlorinated biphenyls and polycyclic aromatic hydrocarbons in Minnesota. Environ. Sci. Technol. 32 (12), 1771-1778.

Fries, E., Püttmann, W., 2004. Occurrence of 4-Nonylphenol in rain and snow. Atmos. Environ. 38 (13), 2013-2016.

Guo, R., Lee, I.S., Kim, U.J., Oh, J.E., 2010. Occurrence of synthetic musks in Korean sewage sludges. Sci. Total. Environ. 408 (7), 1634-1639.

Hu, Z.J., Shi, Y.L., Niu, H.Y., Cai, Y.Q., Jiang, G.B., Wu, Y.N., 2010. Occurrence of synthetic musk fragrances in human blood from 11 cities in China. Environ. Toxicol. Chem. 29 (9), 1877-1882.

Hu, Z.J., Shi, Y.L., Zhang, S.X., Niu, H.Y., Cai, Y.Q., 2011. Assessment of synthetic musk fragrances in seven wastewater treatment plants of Beijing. China. Bull. Environ. Contam. Toxicol. 86 (3), 302-306.

Huang, D.Y., Peng, P.A., Xu, Y.G., Sun, C.X., Deng, H.M., Deng, Y.Y., 2010. Distribution, regional sources and deposition fluxes of organochlorine pesticides in precipitation in Guangzhou, South China. Atmos. Res. 97 (1-2), 115-123.

Käfferlein, H.U., Angerer, J., 2001. Trends in the musk xylene concentrations in plasma samples from the general population from 1992/1993 to 1998 and the relevance of dermal uptake. Int. Arch. Occup. Environ. Health. 74 (7), 470-476.

Kolb, A., Püttmann, W., 2006. Methyl tert-butyl ether (MTBE) in snow samples in Germany. Atmos. Environ. 40 (1), 76-86.

Lafrenère, M.J., Blais, J.M., Sharp, M.J., Schindler, D.W., 2006. Organochlorine pesticide and polychlorinated biphenyl concentrations in snow, snowmelt, and runoff at Bow Lake, Alberta. Environ. Sci. Technol. 40 (16), 4909-4915.

Lei, Y.D., Wania, F., 2004. Is rain or snow a more efficient scavenger of organic chemicals? Atmos. Environ. 38 (22), 3557-3571.

Lignell, S., Darnerud, P.O., Aune, M., Cnattingius, S., Hajslova, J., Setkova, L., Glynn, A., 2008. Temporal trends of synthetic musk compounds in mother's milk and associations with personal use of perfumed products. Environ. Sci. Technol. 42, 6743-6748.

Masclet, P., Hoyau, V., Jaffrezo, J.L., Cachier, H., 2000. Polycyclic aromatic hydrocarbon deposition on the ice sheet of Greenland. Part I: superficial snow. Atmos. Environ. 34 (19), 3195-3207.

Peck, A.M., Hornbuckle, K.C., 2006. Synthetic musk fragrances in urban and rural air of Iowa and the Great Lakes. 40(32), 6101-6111.

Reiner, J., Berset, J., Kannan, K., 2007. Mass flow of polycyclic musks in two wastewater treatment plants. Arch. Environ. Contam. Toxicol. 52 (4), 451-457.

Richardson, S.D., 2009. Water analysis: emerging contaminants and current issues. Anal. Chem. 81 (12), 4645-4677.

Schneidemesser, E.V., Stone, E.A., Quraishi, T.A., Sharfer, M.M., Schauer, J.J., 2010. Toxic metals in the atmosphere in Lahore, Pakistan. Sci. Total. Environ. 408 (7), 1640-1648.

Sempére, R., Kawamura, K., 1994. Comparative distributions of dicarboxylic acids and related polar compounds in snow, rain and aerosols from urban atmosphere. Atmos. Environ. 28 (3), 449-459.

Wan, Y., Wei, O.W., Hu, J.Y. Jin, X.H., Zhang, Z.B., Zhen, H.J., Liu, J.Y., 2007. Levels, tissue distribution, and age-related accumulation of synthetic musk fragrances in Chinese Sturgeon (Acipenser sinensis): comparison to organochlorines. Environ. Sci. Technol. 41, 424-430.

Wang, C.X., Zhu, W., Peng, A., Guichreit, R., 2001. Comparative studies on the concentration of rare earth elements and heavy metals in the atmospheric particulate matter in Beijing, China, and in Delft, the Netherlands. Environ. Int. 26 (5-6), 309-313.

Wang, F., Zhu, T., Xu, B.Q., Kang, S.C., 2007. Organochlorine pesticides in fresh-fallen snow on East Rongbuk Glacier of Mt. Qomolangma (Everest). Sci. China Ser. D-Earth Sci. 50 (7), 1097-1102.

Wania, F., Mackay, D., Hoff, J.T., 1998. The importance of snow scavenging of polychlorinated biphenyl and polycyclic aromatic hydrocarbon vapors. Environ. Sci. Technol. 33 (1), 195-197.

Xie, Z.Y., Ebinghaus, R., Temme, C., Heemken, O., Ruck, W., 2007. Air-sea exchange fluxes of synthetic polycyclic musks in the North Sea and the Arctic. Environ. Sci. Technol. 41 (16), 5654-5659.

Xu, Z.F., Han, G.L., 2009. Chemical and strontium isotope characterization of rainwater in Beijing, China. Atmos. Environ. 43, 1954-1961.

Yamauchi, R., Ishibashi, H., Hirano, M., Mori, T., Kim, J.W., Arzono, K., 2008. Effects of synthetic polycyclic musks on estrogen receptor, vitellogenin, pregnane $\mathrm{X}$ receptor, and cytochrome P4503A gene expression in the livers of male medaka (Oryzias latipes). Aquat. Toxicol. 90 (4), 261-268.

Zhang, W., Zhang, S.C., Yue, D.P., Ye, Y.B., Wang, X.J., 2008. Source diagnostics of polycyclic aromatic hydrocarbons in urban road runoff, dust, rain and canopy throughfall. Environ. Pollut. 153, 594-601.

Zheng, N., Liu, J.S., Wang, Q., Liang, Z.Z., 2010. Heavy metals exposure of children from stairway and sidewalk dust in the smelting district, northeast of China. Atmos. Environ. 44 (27), 3239-3245.

Zhou, H., Huang, X., Gao, M.J., Wang, X.L., Wen, X.H., 2009. Distribution and elimination of polycyclic musks in three sewage treatment plants of Beijing, China. J. Environ. Sci. 21 (5), 561-567. 